\title{
ON THE LIVERWORT FLORA OF TUNKINSKIY NATIONAL PARK (REPUBLIC OF BURYATIA, RUSSIA)
}

\author{
К ФЛОРЕ ПЕЧЕНОЧНИКОВ ТУНКИНСКОГО НАЦИОНАЛЬНОГО ПАРКА \\ (РЕСПУБЛИКА БУРЯТИЯ, РОССИЯ)
}

\author{
NADEZHDA A. KONSTANTINOVA ${ }^{1}$, YURi S. MAMONTOV ${ }^{2,3} \&$ ANATOLY N. SAVCHENKO $^{1}$ \\ НАДЕЖДА А. КОНСТАНТИНОВА ${ }^{1}$, ЮРИЙ С. МАМОНТОВ ${ }^{2,3}$, АНАТОЛИЙ Н. САВЧЕНКО $^{1}$
}

Abstract

\begin{abstract}
An annotated list of hepatics of the Tunkinskiy National Park (on the southern slopes of the Eastern Sayan and Tunka depression, South Siberia) was compiled for the first time based on identification of specimens collected by the authors and some specimens of Siberian collectors. The list includes 75 species, one subspecies and two varieties collected almost exclusively in the forest zone. The distribution and ecology of a number of worldwide rare liverworts (Mesoptychia igiana, M. morrisoncola, Oleolophozia perssonii, Scapania carinthiaca, S. gymnostomophila) is expanded. Androecia of Mesoptychia igiana were found and are described from Russia for the first time. The specific features of the liverwort flora of Tunka National Park are discussed.
\end{abstract}

Резюме

\begin{abstract}
Впервые составлен аннотированный список печеночников Тункинского национального парка (южные склоны Восточного Саяна, северные склоны Хангарульского хребта, Тункинская котловина, республика Бурятия). Список подготовлен на основе идентификации сборов авторов и нескольких образцов сибирских ботаников и включает 75 видов, один подвид и 2 разновидности собранные в основном в лесном поясе. Выявлены новые местонахождения редких в мире и печеночников (Mesoptychia igiana, M. morrisoncola, Oleolophozia perssonii, Scapania carinthiaca, S. gymnostomophila и др.). Впервые в России найдены и описаны андроцеи Mesoptychia igiana. Обсуждается специфика флоры печеночников Тункинского национального парка, заключающаяся в относительно большой доле во флоре кальцефильных, а также восточноазиатских печеночников.
\end{abstract}

KEYWORDS: Hepatics, distribution, phytogeography, ecology, flora, Eastern Sayan, Khamar-Daban Ridge, Tunka depression, South Siberia, Russia

\section{INTRODUCTION}

In the last decade the study of the diversity of liverworts in several regions of South Siberia has intensified. As a result some species new to science (Sofronova et al., 2013; Mamontov \& Vilnet, 2017) or new to Russia (Mamontov, 2013a; Mamontov \& Vilnet, 2013; Sofronova et al., 2014; Potemkin et al., 2015) and new to Siberia (Mamontov et al., 2011; Mamontov \& Afonina, 2012; Afonina et al., 2013; Tubanova et al., 2017) have been found, and the distribution of many species has been greatly expanded. Annotated lists of species were compiled for the Katunsky (Mamontov, 2013b), Sokhondinsky (Afonina et al., 2012) and Dzherginskiy (Mamontov, 2018) reserves, the Atsinsky Sanctuary (Czernyadjeva et al., 2013), the Zabaikalsky National Park (Afonina et al., 2018) and the Irkutsk Province (Mamontov \& Konstantinova, 2017).
South Siberia is a vast territory with high mountains with elevations up to $4506 \mathrm{~m}$ (e.g. in Altai Mts.), and liverworts have not yet been studied for large areas. One such territory is Tunkinskiy National Park. Until now nothing was known about the liverwort flora of the park territory. We studied liverworts of the park and the compiled list of species is obviously not complete because the liverwort flora of the subalpine and alpine zones was not studied at all. Nevertheless the obtained data fill a gap in our knowledge on distribution and ecology of liverworts in South Siberia including worldwide rare and poorly known species. Taking the importance of the study of flora and vegetation of protected areas into account and that no data on liverworts of Tunka National Park has ever been published, we find it useful to publish an annotated list of species that we have found in the Park.

\footnotetext{
1 - Polar-Alpine Botanical Garden, Kola Sci. Centre, Russ. Acad. Sci., Kirovsk-6, Murmansk Province, 184256 Russia - Poccия 184256, Мурманская область, г. Кировск-6, Полярно-альпийский ботанический сад-институт КНЦ РАН. Е-mails: nadya50@list.ru, anatsav50@list.ru

2 - Botanical Garden-Institute, Far Eastern Branch, Russ. Acad. Sci., Makovskogo 142, 690024, Vladivostok, Russia - Poccия 690024, Владивосток, Маковского 142, Ботанический сад-институт ДВО РАН. E-mail: yur-mamontov@yandex.ru

3 - Tsitsin Main Botanical Garden, Russ. Acad. Sci., Botanicheskaja 4, 127276, Moscow, Russia - Россия 127276, Москва, Ботаническая 4, Главный ботанический сад им. Н.В. Цицина РАН.
} 


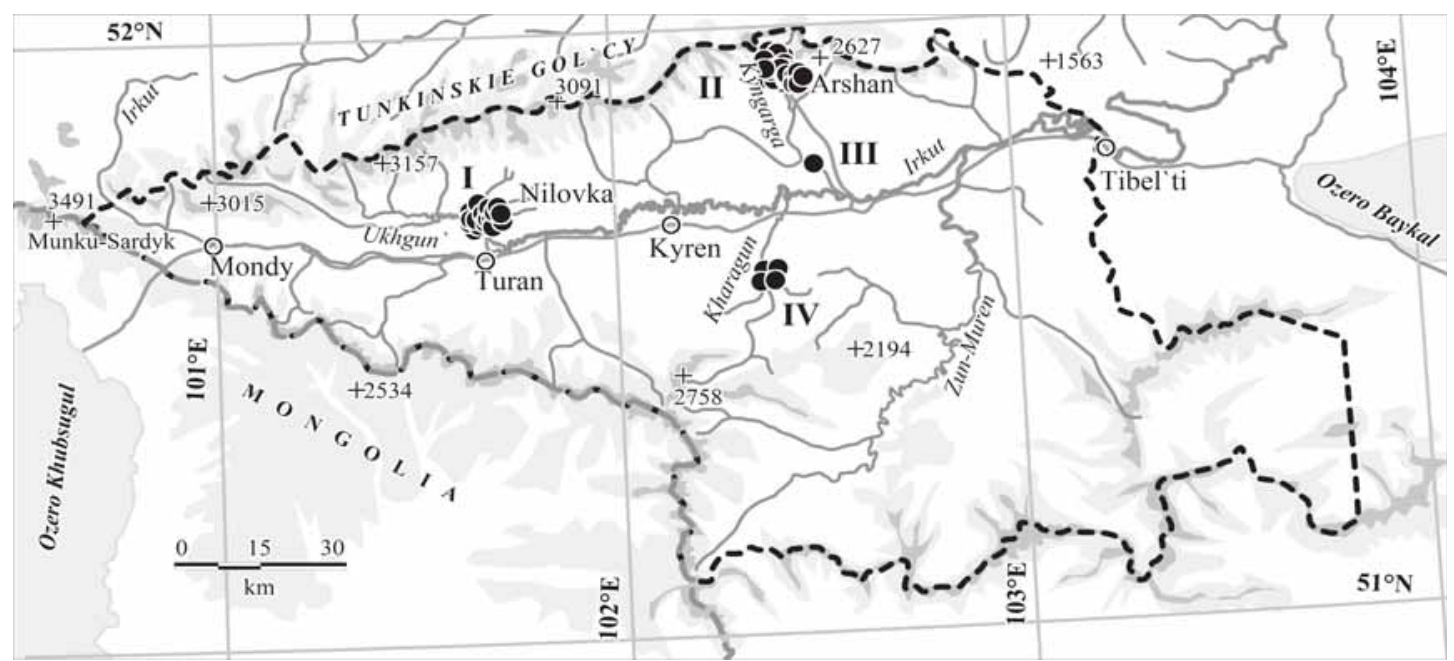

Fig. 1. Collecting localities, shown as four groups, I-IV.

I. Valley of Ekhe-Ukhgun' River near the town of Nilovka.

1. Flood plain of Khongolboy Creek (right tributary of Ukhe-Ukhgun' River), Larix sibirica with Abies green moss forest, $51^{\circ} 42^{\prime} 28^{\prime \prime} \mathrm{N}-101^{\circ} 39^{\prime} 22^{\prime \prime} \mathrm{E}$, $916 \mathrm{~m}$ alt. 2. Right bank of Ekhe-Ukhgun' River, $51^{\circ} 42^{\prime} 13^{\prime \prime} \mathrm{N}-101^{\circ} 39^{\prime} 40^{\prime \prime} \mathrm{E}, 907 \mathrm{~m}$ alt. 3. Right bank of Ekhe-Ukhgun' River, $51^{\circ} 41^{\prime} 41^{\prime \prime} \mathrm{N}-101^{\circ} 40^{\prime} 10^{\prime \prime} \mathrm{E}$, $898 \mathrm{~m}$ alt. 4. Rock outcrops on right bank of Ekhe-Ukhgun' River, $51^{\circ} 41^{\prime} 41^{\prime \prime} \mathrm{N}-101^{\circ} 40^{\prime} 9^{\prime \prime} \mathrm{E}, 900 \mathrm{~m}$ alt. 5. Cliffs in birch forest on right bank of Malyi Khongolboy Creek (right tributary of Ekhe-Ukhgun' River), 51 ${ }^{\circ} 41^{\prime} 32^{\prime \prime} \mathrm{N}-101^{\circ} 40^{\prime} 52^{\prime \prime} \mathrm{E}, 908 \mathrm{~m}$ alt. 6. Rock outcrops on steep slope in pine forest on right bank of Malyi Khongolboy Creek (right tributary of Ekhe-Ukhgun' River), 51 ${ }^{\circ} 41^{\prime} 34^{\prime \prime} \mathrm{N}-101^{\circ} 40^{\prime} 50^{\prime \prime} \mathrm{E}, 926 \mathrm{~m}$ alt. 7. Larix dominated with Abies and Betula and Equisetum in ground cover forest in floodplain of Khongolboy creek (right tributary of Ekhe-Ukhgun' River), 51 ${ }^{\circ} 41^{\prime} 57^{\prime \prime} \mathrm{N}-101^{\circ} 41^{\prime} 22^{\prime \prime} \mathrm{E}$, $926 \mathrm{~m}$ alt. 8. Abies and Betula with Equisetum in ground cover forest in floodplain of Khongolboy creek 51 $41^{\prime} 58^{\prime \prime} \mathrm{N}-101^{\circ} 41^{\prime} 31^{\prime \prime} \mathrm{E}, 929 \mathrm{~m}$ alt. 9 . Rock

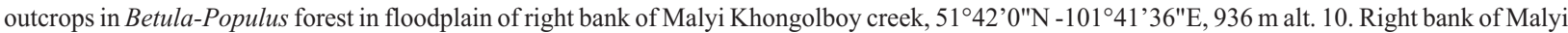
Khongolboy Creek, Larix sibirica-Picea-Betula forest, 51 ${ }^{\circ} 42^{\prime} 2^{\prime \prime} \mathrm{N}-101^{\circ} 41^{\prime} 48 " \mathrm{E}, 937 \mathrm{~m}$ alt. 11. Right bank of Malyi Khongolboy Creek, Larix-Pinus sibirica-Picea with admixture of Betula forest, $51^{\circ} 42^{\prime} 7^{\prime \prime} \mathrm{N}-101^{\circ} 42^{\prime} 0^{\prime \prime} \mathrm{E}, 941 \mathrm{~m}$ alt. 12. Right bank of Malyi Khongolboy Creek, rock outcrops in Populus tremula forest on steep slope, 51 $42^{\prime} 3^{\prime \prime} \mathrm{N}-101^{\circ} 41^{\prime} 44^{\prime \prime} \mathrm{E}, 939 \mathrm{~m}$ alt. 13. Right bank of Ekhe-Ukhgun', boulder scree and cliffs along the road, $51^{\circ} 41^{\prime} 44^{\prime \prime} \mathrm{N}-101^{\circ} 39^{\prime} 55^{\prime \prime E}, 933 \mathrm{~m}$ alt. 14. Right bank of Ekhe-Ukhgun' River, rock outcrops in secondary birch forest, 51 ${ }^{\circ} 41^{\prime} 44^{\prime \prime} \mathrm{N}-101^{\circ} 39^{\prime} 55^{\prime \prime} \mathrm{E}, 917$ $\mathrm{m}$ alt. 15. Right bank of Ekhe-Ukhgun' River, rock outcrops and cliffs, 51 ${ }^{\circ} 41^{\prime} 47^{\prime \prime} \mathrm{N}-101^{\circ} 39^{\prime} 52^{\prime \prime} \mathrm{E}, 899 \mathrm{~m}$ alt. 16. Right bank of Ekhe-Ukhgun' River, mossy rock outcrops near the road, $51^{\circ} 42^{\prime} 13^{\prime \prime} \mathrm{N}-101^{\circ} 39^{\prime} 37^{\prime \prime} \mathrm{E}, 916 \mathrm{~m}$ alt. 17. Right bank of Ekhe-Ukhgun' River near the bridge in Nilovka, 51 ${ }^{\circ} 42^{\prime} 14^{\prime \prime} \mathrm{N}$ - ^39’36"E, 914 m alt.

\section{IIa. Valley of Kyngarga River}

1. Calcareous cliffs on left bank of river, $51^{\circ} 55^{\prime} 18^{\prime \prime} \mathrm{N}-102^{\circ} 25^{\prime} 32^{\prime \prime} \mathrm{E}, 926 \mathrm{~m}$ alt. 2. Pine forest with Betula and single aspen and sporadic sedge in the cover on slope to the river $51^{\circ} 55^{\prime} 25^{\prime \prime} \mathrm{N}-102^{\circ} 25^{\prime} 31^{\prime \prime E}, 935 \mathrm{~m}$ alt. 3. Steep west faced slope to the river in gorge with waterfall, $51^{\circ} 55^{\prime} 35^{\prime \prime} \mathrm{N}-102^{\circ} 25^{\prime} 27^{\prime \prime} \mathrm{E}, 965 \mathrm{~m}$ alt. 4. Rock outcrops 10 meters above the water level on left bank of river in gorge with waterfall $51^{\circ} 55^{\prime} 39^{\prime \prime} \mathrm{N}-102^{\circ} 25^{\prime} 26^{\prime \prime} \mathrm{E}, 976 \mathrm{~m}$. lat. 5. Rock outcrops and cliffs on left bank of river in gorge with waterfall, $51^{\circ} 55^{\prime} 45^{\prime \prime} \mathrm{N}-102^{\circ} 25^{\prime} 20^{\prime \prime} \mathrm{E}, 975 \mathrm{~m}$ alt. 6. Rock outcrops on right bank of river in gorge with waterfall, $51^{\circ} 55^{\prime} 47^{\prime \prime} \mathrm{N}-102^{\circ} 25^{\prime} 19^{\prime \prime} \mathrm{E}, 1081 \mathrm{~m}$ alt. 7 . Moist side of huge covered by mosses boulder on left bank of river in gorge with waterfall, $51^{\circ} 55^{\prime} 49^{\prime \prime} \mathrm{N}-$ $102^{\circ} 25^{\prime} 19^{\prime \prime} \mathrm{E}, 1055 \mathrm{~m}$ alt. 8. Moist cliff on right bank of river in gorge with waterfall, $51^{\circ} 55^{\prime} 48^{\prime \prime} \mathrm{N}-102^{\circ} 25^{\prime} 19^{\prime \prime}, 1103 \mathrm{~m}$ alt. 9 . Right bank of the river upstream of waterfall, $51^{\circ} 55^{\prime} 51^{\prime \prime} \mathrm{N}-102^{\circ} 25^{\prime} 19^{\prime \prime} \mathrm{E}, 1110 \mathrm{~m}$ alt. 10 . Right bank of the river upstream of waterfall, $51^{\circ} 55^{\prime} 53^{\prime \prime} \mathrm{N}-102^{\circ} 25^{\prime} 24^{\prime \prime}, 1093 \mathrm{~m}$ alt. 11 . Cliffs on right bank of the river upstream of waterfall, $51^{\circ} 55^{\prime} 55^{\prime \prime} \mathrm{N}-102^{\circ} 25^{\prime} 30^{\prime \prime} \mathrm{E}, 1119 \mathrm{~m}$ alt. 12 . Right bank of the river upstream of waterfall, on huge boulder under Abies, $51^{\circ} 55^{\prime} 53^{\prime \prime} \mathrm{N}-102^{\circ} 25^{\prime} 28^{\prime \prime} \mathrm{E}, 1153 \mathrm{~m}$ alt. 13. Rock outcrops in Pinus sibirica sedge-moss forest on north-faced steep left side of deep gorge of Kyngarga River, $51^{\circ} 55^{\prime} 54^{\prime \prime N}-102^{\circ} 25^{\prime} 22^{\prime \prime E}, 1190 \mathrm{~m}$ alt. 14. Pinus sibirica sedge-moss forest on north-faced steep left side of deep gorge of river, $51^{\circ} 55^{\prime} 50^{\prime \prime} \mathrm{N}-102^{\circ} 25^{\prime} 27^{\prime \prime E}, 1266 \mathrm{~m}$ alt. 15. Decaying $\log$ of Larix in Populus dominated forest on steep west faced slope. 51 ${ }^{\circ} 55^{\prime} 47^{\prime \prime} \mathrm{N}-102^{\circ} 25^{\prime} 25^{\prime \prime} \mathrm{E}, 1145$ $\mathrm{m}$ alt. 16.The side of decaying $\log$ of Larix? in Populus dominated forest on steep west faced slope, $51^{\circ} 55^{\prime} 46^{\prime \prime} \mathrm{N}-102^{\circ} 25^{\prime} 23^{\prime \prime} \mathrm{E}, 1074 \mathrm{~m}$ alt. 17. The outskirts of the town of Arshan, a small island between two courses of the river, $51^{\circ} 55^{\prime} 19^{\prime \prime} \mathrm{N}-102^{\circ} 25^{\prime} 33^{\prime \prime} \mathrm{E}, 923 \mathrm{~m}$ alt. 18. Larix sibirica-Pinus sylvestris-Betula platyphylla-Populus tremula-Salix sp.-Rhododendron dahuricum-Rosa sp.-grass forest on W-facing mountain slope.

\section{IIb Near Arshan, along the trail to Artem'ev Lake}

19. Trail in Larix-Pinus silvestris-Betula-Pinus sibirica-Maianthemum bifolium motley-grass forest, $51^{\circ} 54^{\prime} 56^{\prime \prime} \mathrm{N}-102^{\circ} 26^{\prime} 59^{\prime \prime} \mathrm{E}, 972 \mathrm{~m}$ alt. 20. Larix-Betula-Pinus silvestris forest with admixture of Populus and Bergenia crassifolia in ground cover forest over boulder scree with moss covered boulders, $51^{\circ} 54^{\prime} 56^{\prime \prime} \mathrm{N}-102^{\circ} 27^{\prime} 28^{\prime \prime} \mathrm{E}, 990 \mathrm{~m}$ alt. 21 . The track of mudslides happened in $2014,51^{\circ} 54^{\prime} 57^{\prime \prime} \mathrm{N}-102^{\circ} 27^{\prime} 33^{\prime \prime} \mathrm{E}, 987 \mathrm{~m}$ alt. 22 . Pinus silvestris dominated forest with admixture of Betula and Pinus sibirica, Bergenia crassifolia in ground cover, 51 ${ }^{\circ} 54^{\prime} 57^{\prime \prime} \mathrm{N}-102^{\circ} 27^{\prime} 44^{\prime \prime} \mathrm{E}, 996 \mathrm{~m}$ alt. 23. Pinus silvestris with admixture of Betula and Pinus sibirica, single Larix and Bergenia crassifolia ground cover forest, 51 ${ }^{\circ} 54^{\prime} 57^{\prime \prime} \mathrm{N}-102^{\circ} 27^{\prime} 47^{\prime \prime} \mathrm{E}, 1006 \mathrm{~m}$ alt. 24. Pinus silvestris forest with admixture of Betula, single trees of Pinus sibirica and Bergenia crassifolia cover, $51^{\circ} 54^{\prime} 56^{\prime \prime} \mathrm{N}-102^{\circ} 27^{\prime} 57^{\prime \prime} \mathrm{E}, 1016$ $\mathrm{m}$ alt. 25. Boulder scree, with boulders covered by lichens bordered with Pinus silvestris-Populus tremula forest with Myrthus and Bergenia crassifolia in ground cover $51^{\circ} 55^{\prime} 0^{\prime \prime} \mathrm{N}-102^{\circ} 28^{\prime} 5^{\prime \prime} \mathrm{E}, 1047 \mathrm{~m}$ alt. 26 Boulder scree with rocks covered by bryophytes and lichens on the edge of forest with dominance of Pinus sibirica and admixture of Larix and Betula, 51 ${ }^{\circ} 55^{\prime} 14^{\prime \prime} \mathrm{N}-102^{\circ} 28^{\prime} 19^{\prime \prime} \mathrm{E}, 1130 \mathrm{~m}$ alt.

IIc Near Arshan Peak.

27. Larix sibirica-Pinus sylvestris-Betula platyphylla-Salix sp.-Rhododendron dahuricum-Ledum palustre-Bergenia crassifolia-Vaccinium vitisidaea-moss forest on $\mathrm{W}$-facing mountain slope, $51^{\circ} 55^{\prime} 51.9^{\prime \prime} \mathrm{N}-102^{\circ} 25^{\prime} 44.6^{\prime \prime} \mathrm{E}, 1235 \mathrm{~m}$ alt. 28. Larix sibirica-Pinus sibirica-Rhododendron adamsiiDryas sp. (or Rosa sp.)-grass forest on north-facing rocky slope, 51 ${ }^{\circ} 56^{\circ} 18.0^{\prime \prime} \mathrm{N}-102^{\circ} 26^{‘} 25.7^{\prime \prime} \mathrm{E}, 1739 \mathrm{~m}$ alt. 29. Caragana jubata-Dryas sp.-grass community on S-facing, 51 $56^{\circ} 29.6^{\prime \prime} \mathrm{N}-102^{\circ} 26^{\prime} 23.6^{\prime \prime} \mathrm{E}, 1906 \mathrm{~m}$ alt.

III. Valley of Tunka River

1. Right bank of Tunka River near the bridge, $51^{\circ} 45^{\prime} 47^{\prime \prime} \mathrm{N}-102^{\circ} 31^{\prime} 25^{\prime \prime} \mathrm{E}, 711 \mathrm{~m}$ alt.

IV. Spurs of Khangarul'skiy Ridge, valley of Kharagun River

1. Brook in forest with mossy rocks in bed, $51^{\circ} 36^{\prime} 24^{\prime \prime N}-102^{\circ} 21^{\prime} 52^{\prime \prime} \mathrm{E}, 853 \mathrm{~m}$ alt. 2. Picea abies with Pinus silvestris and Picea obovata forest, $51^{\circ} 36^{\prime} 1^{\prime \prime N}-102^{\circ} 21^{\prime} 33^{\prime \prime E}, 870 \mathrm{~m}$ alt. 3. Right bank of Kharagun River, $51^{\circ} 35^{\prime} 44^{\prime \prime} \mathrm{N}-102^{\circ} 20^{\prime} 50^{\prime \prime} \mathrm{E}, 884 \mathrm{~m}$ alt. 4. Rock outcrops on right bank of Khyngarkhoy River, $51^{\circ} 35^{\prime} 43^{\prime \prime} \mathrm{N}-102^{\circ} 20^{\prime} 47 " \mathrm{E}, 882 \mathrm{~m}$ alt. 

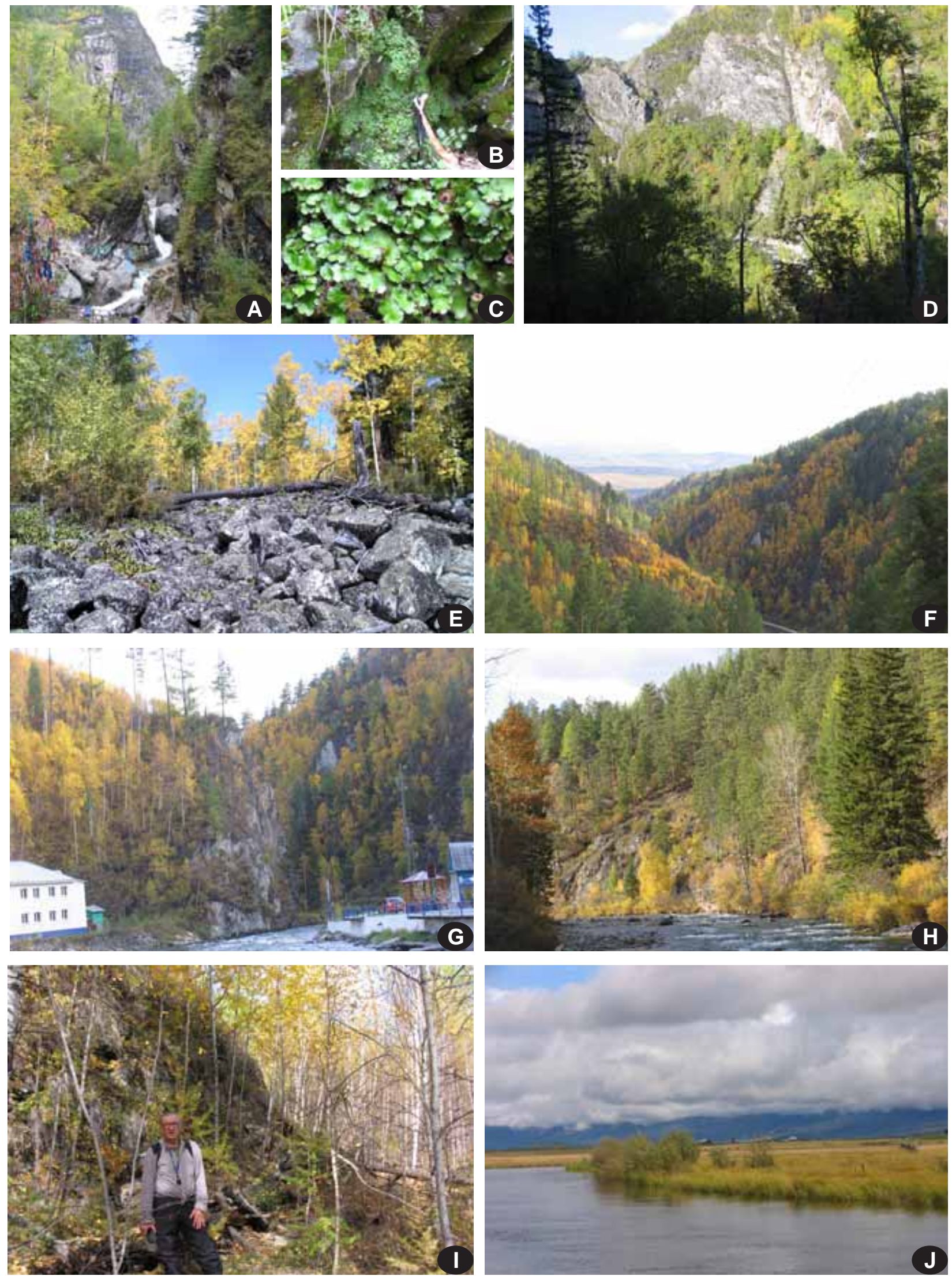

Fig. 2. A: the waterfall in the gorge of the Kyngarga River (site IIa); B: mats of Plagiochasma pterospermum near waterfall; C: Plagiochasma pterospermum; D: Kyngarga River Gorge upstream the waterfall; E: boulder scree (site IIb:25); F: valley of EkheUkhgun' River; G: cliffs on the left bank of Ekhe-Ukhgun' River; H: cliffs on the right bank of Ekhe-Ukhgun' River; I: rock outcrops on right bank of Malyi Khongolboy creek (site I: 9); J: valley of Tunka River (site III). 


\section{MATERIAL AND METHODS}

The study is mainly based on specimens collected by Nadezhda Konstantinova and Anatoliy Savchenko during nine days in 2017. In total 193 specimens were collected from September 6th to 10th, September 13th and September 15 th to 17 th. During a one day collection trip ca. 15 specimens were collected by Yu. Mamontov near Arshan Peak in 2015. We also studied a few specimens of L.V. Bardunov as well as N. Schevyreva \& T. Konovalova that we received from IRK. The majority of the specimens (115) were collected on the southern slopes of the Eastern Sayan Mountains near the town of Arshan in the Kyngarga River valley, along the trail to Artem'ev Lake and near Arshan Peak (Fig. 1: II). A rather big collection was gathered in the Ekhe-Ukhgun' River valley near the town of Nilovka (71 specimens). During a halfday collecting trip we gathered liverworts in the Kharagun River valley - the only locality studied in the spurs of Khangarul'skiy Ridge (ca. 20 specimens). Only one specimen was collected in the valley of Tunka River in the steppe zone. In total 208 specimens were gathered in four areas (Figs. 1,2). The majority of the collections derive from the forest zone, only a few specimens were gathered in the subalpine zone and none in the alpine zone. For all localities except the old collections of L.V. Bardunov and N. Schevyreva \& T. Konovalova, the coordinates and elevations were measured using GPS. The collected specimens were studied in the laboratory of the Polar-Alpine Botanical Garden-Institute (Kirovsk, Murmansk Province). The specimens are deposited in the Herbarium of Polar-Alpine Botanical Garden-Institute of the Kola Scientific Center, Russian Academy of Sciences (KPABG). Label data are incorporated in the CRIS Cryptogamic Russian Information System (https:// kpabg.ru>cris/?q=node/16).

\section{STUDY AREA}

Tunkinsky National Park (also called Tunka National Park), South Siberia occupies $11,837 \mathrm{~km}^{2}$ the entirety of the Tunkinsky District of the Republic of Buryatia. The heights of the mountains here range from 668 meters in the Tunka Depression to 3172 meters in the highest mountain of the Munku-Sardyk area (https://en.wikipedia.org/wiki/Tunkinsky_National_Park). In addition to the Tunkinskaya Depression that occupies the greater part of the park, it includes the southern slopes of the Eastern Sayan (Tunkinskie Goltsy) and the northern slopes of the Khamar-Daban Ridge. A significant part of the slopes of Eastern Sayan within the park consists of interstratified calcareous shale and marbles. It defines the presence of carbonate outcrops particularly in the Kyngarga and Ekhe-Ukhgun' river valleys. The geography of the region is very diverse and includes rift and glacial valleys, high mountains with deep gorges, steep slopes, cliffs, rock outcrops, block screes, both slow moving rivers and rapid mountain streams with rapids and waterfalls, hot springs, and associated habitats. The climate is conti- nental with wide fluctuations of daily and annual temperature. The mean temperature of January is minus 24 $25^{\circ}$ and July plus $17-18^{\circ}$ (https://en.wikipedia.org/wiki/ Tunkinsky_National_Park). The four vegetation zones present in the Tunka National Park are steppes extended upward as high as $1000 \mathrm{~m}$ alt., forests, rising up to 1500 $1800 \mathrm{~m}$ alt. and subalpine and alpine zones above that. The Kyngarga River (on the southern slope of the Eastern Sayan Mountains) near Arshan flows in a deep canyon with huge mossy blocks on steep slopes, waterfall and rapids (Fig. 2A). The diversity of appropriate habitats for liverworts is very high here (Fig. 1, site IIa) including cliffs, rock outcrops, blocks on banks of the river and in the forests on sides of the gorge as well as logs and different decaying wood in coniferous forests on steep slopes, bare loamy soil and rocks along the trail. The second studied area is the Ekhe-Ukhgun' River valley (a tributary of the Irkut River) near Nilovka (Fig. 1, site I) that is situated in the Nilovskiy Spur of the Eastern Sayan Mountains. The collecting sites here include rock outcrops and cliffs in mountain forests on steep sides of the Ekhe-Ukhgun' River, banks of the river and its tributaries, forests in floodplain and on slopes to the Malyi Khongolboy creek (Fig. 2F-1). Some obligate calcicoles including Plagiochasma spp., Targionia hypophylla, Scapania cuspiduligera, are not rare there and in some sites even abundant.

On the southern slope of Eastern Sayan along the trail to Artem'ev Lake (Fig. 1, site IIb) we collected liverworts in forests and on block screes in one day trip. In these sites widespread species of decaying wood and mossy block screes in different type of forests were collected. Several specimens were gathered by Mamontov in the subalpine zone near Arshan Peak (Fig. 1, site IIc). We also studied two specimens from the subalpine zone collected by N. Schevyreva and T. Konovalova at around $1500 \mathrm{~m}$ altitude and one specimen collected by L.V. Bardunov. During a full day's work we only collected one species (Riccia cf. cavernosa) in the steppe zone of the Tunka Depression (Fig. 1, site III). It is a huge area covered by lakes and boggy meadows that are traditionally used as pastures (Fig. 2J).

The only area on the northern slope of the KhamarDaban mountain range that we studied, is at the GurbiDaban Range is the valley of the river Haragun near the mineral spring Hongor-Uula (Fig. 1, site IV). In this area rocks are represented by amphibole-biotite gneiss and crystalline schists.

\section{LIST OF SPECIES}

The annotated list of hepatics includes 75 species, 2 subspecies and 2 varieties. The nomenclature generally follows Söderström et al. (2016). Some synonyms that are common in Russian publications are cited in brackets. After the species name the presence of reproductive structures is given in parentheses (and. - androecia; gyn. - gynoecia; per. - perianths or pseudoperianths; spor. sporophytes; gem. - gemmae). The collecting sites are 
listed according Fig. 1, followed by the number of specimens preserved in KPABG; the altitudinal range (in meters) is indicated after a colon. Habitat characteristics and accompanying species are given for sporadic and widespread species and at least one reference to herbarium number in the Cryptogamic Russian Information System - CRIS (kpabg.ru>cris/ ?q=node/16) is cited. For species collected from 1-2(3) localities the labels are cited in full and the reference to the herbarium number in the Herbarium of Polar-Alpine Botanical Garden-Institute $(\mathrm{KPABG})$ is given.

Aneura pinguis (L.) Dumort. - I: 17; IIa: 10, 17; IIc: 28 (6: 9141093). On loamy soil on rocks overhanging by grasses, on slopes to rivers, on tussocks near water, once on trail between roots and rocks. In pure mats or mixed with Blepharostoma trichophyllum, Mesoptychia igiana, M. morrisoncola, Scapania cuspiduligera etc. [121915].

Arnellia fennica (Gottsche) Lindb. - I: 15, 16, 17 (6: 899-916 $\mathrm{m})$. On dead mosses and on soil, in crevices, on litterfall covered rocks, on mossy boulders, on bank of river. In pure mats or mixed with Blepharostoma trichophyllum, Lophocolea heterophyllum, Reboulia hemisphaerica, Trilophozia quinquedentata [122021].

Barbilophozia barbata (Schmidel ex Schreb.) Loeske - I: 13 IIa: 3, 11, IIb.: 20, 26; VI:4 (9: 882-1130). On rocks, on mosses and soil on sides of boulders in boulder screes, on decaying almost destroyed wood and on soil on steep slopes in mixed forests. Often in pure mats or mixed with Frullania davurica, Plagiochila porelloides, Porella gracillima, Scapania degenii, Ptilidium pulcherrimum, Tritomaria exsecta [122017].

B. hatcheri (A. Evans) Loeske. - IIc: 27 (1:1739 m). In rock fissures, with Ptilidium ciliare [122053]

Blasia pusilla L. (gem.) - I:1. (1:916 m). On sandy soil between rocks on bank of brook [121957].

Blepharostoma trichophyllum (L.) Dumort. (per.) - I: 1, 17; IIa: 10, 14; VI: 3, 4 (17: 882-1500). On soil covered rocks, on soil between rocks, on banks of rivers, on trails under roots sticking out and on mossy logs in mixed forests, in pure mats or mixed with other bryophytes [121947]

Calypogeia suecica (Arnell et J. Perss.) Müll. Frib. (gem.) - I: 7 (4: 926 m). On log of Larix sibirica, mixed with Crossocalyx hellerianus, Syzygiella autumnalis, Lophocolea heterophylla, Ptilidium pulcherrimum [121989].

Cephaloziella arctogena (R.M. Schust.) Konstant. (per., and., paroicous) - IIb: 23 (2:1006 m). On mossy log on edge of mats with mixture of Lepidozia reptans and Syzygiella autumnalis [121890].

C. divaricata (Sm.) Schiffn. - IIa: 3 (3: 965 m). On rock, mixed with Lophoziopsis excisa_ [121835]; IIb: 26 (1130 m), under rock, mixed with Tritomaria exsectiformis [121903].

C. elegans (Heeg) Schiffn. (per., and., paroicous) - IIb: 26 (3:1047-1130). At the base of boulder, with admixture of single shoots of Syzygiella autumnalis, Ptilidium pulcherrimum [121907 24]; on moist log, with Ptilidium pulcherrimum [121901].

Chiloscyphus pallescens (Ehrh.) Dumort. - I: 2 (4: 907-914 $\mathrm{m})$. On dense soil on side of trail, with admixture of Mesoptychia badensis (oil bodies 6-7 per cell, cells ca. 35-37 $\mu \mathrm{m}$ in the middle of leaves) [121961]; 17 - in niche, on soil [122037].
C. polyanthos (L.) Corda - I: 2 (5: 853-914). On loamy soil covered boulder near water (cells ca. $25 \mu \mathrm{m}$ in the middle, oil bodies 3-4 per cell), in pure mats [121966]; K373-7-17 (pure mats, oil-bodies mainly 3 per cell, cells ca. 22-25 $\mu \mathrm{m}$ wide) and on side of tussock in pure mats [122039]; IV: 1 in water, on rock with admixture of Pellia neesiana [121927] or Scapania scandica [121925].

Clevea hyalina (Sommerf.) Lindb. - IIc: 28 (1: 1906 m). On soil in rock fissures, several thalli [122055].

Conocephalum conicum (L.) Dumort. - I: 2. Between boulders in pure mats [K348-17]. The species was just noted and not collected.

Crossocalyx hellerianus (Nees ex Lindenb.) Meyl. (per., and., spor., gem.) - I: 3, 7, 11; IIa: 15, 16; IIb: 24 (16: 898-1145m). On moist decaying wood and logs of mostly coniferous trees (Abies sibirica, Pinus sibirica, Larix sibirica) in wet mixed forests in floodplain of rivers and on sides of gorges. Usually mixed with other hepatics of decaying wood, more often with Lophocolea heterophylla, Lepidozia reptans, Tritomaria execta, Riccardia latifrona, Scapania carinthiaca, Syzygiella autumnalis [121892].

Frullania bolanderi Austin - I: 3, 8; IIa: 2; IV: 2 (8: 870-937). On 30-40 cm wide birch and aspen trunks at height of 1-2 $\mathrm{m}$ in mixed forests on slopes of deep gorges sometimes on logs in coniferous forests in pure mats [121933] or mixed with Frullania koponenii [121831].

F. cleistostoma Schiffn. et W. Wollny (and., per. autoicous) - I: 6 (K358-2-17). On ledges of cliffs, mixed with Frullania parvistipula. This long forgotten species has erroneously been synonymized with the North American taxon $F$. inflata (the reinstatement will soon be published).

F. davurica Hampe ex Gottsche, Lindenb. et Nees - I: 2; IIa: 5, 7, 8, 11; IIb: 21, 26; IIc: 27 (17: 975-1119 m). On cliffs, on side of huge boulders covered by mosses in forests and in boulder screes, on mossy rock outcrops, often in huge pure mats [121852] or with admixture of other hepatics characteristic for such sites, e.g. Plagiochila porelloides, Barbilophozia barbata, Porella gracillima, Trilophozia quinquedentata etc.

F. koponenii S. Hatt. (gem.) - I: 8, 10, 17; IIa: 2; IIc: 27; IV: 4 (8: 882-1235). Occurs mostly on bark of trunks of aspen and birch in mixed forests in pure mats [121914] or with Frullania bolanderi [121831], rare on cliffs where with F. parvistipula [121951].

F. parvistipula Steph. - I: 16; IIa: 12; IIb: 26; IIc: 27; IV: 4 (5: $882-1153 \mathrm{~m})$. On huge boulders and cliffs in mixed forests on steep slopes in valley of rivers [121869], once on bark of Populus sp. [121900].

Herbertus aduncus (Dicks.) Gray - I: In spruce forest on north facing slope, on boulders [122066], coll. 17.06.81, L.V. Bardunov; IIc: 28 . In rock fissures, dominated in mats with admixture of Marsupella emarginata, Trilophozia quinquedentata [122052].

Jungermannia atrovirens Dumort. (per., sporog.) - IIa: 10. On slope to the river [121863]; 14. On steep side to the trail, single plants mixed with Oleolophozia perssonii [121879]. IV: 1 . In water, on rock [121926].

$J$. cf. borealis Damsh. et Váňa - IV: 3. On soil covered rock, single plants mixed with Scapania crassiretis [121935] or scattered in mats dominated by Blepharostoma trichophyllum, and admixture of Scapania crassiretis and S. undulata [121936]. 
J. exsertifolia Steph. - I: 2. On loamy soil covered boulders near water, in pure mats [121965 and 121964].

Lepidozia reptans (L.) Dumort. - I: 3, 4; IIa:7, 13; IIb: 22, 23, 24, 26; IV: 2, 4 (16: 870-1235). On rocks, mossy logs and decaying wood in forests on steep slopes, on rocks in screes and rock outcrops. In pure mats [121889] or mixed with Tritomaria spp., Lophozia silvicola, Syzygiella autumnalis, Ptilidium pulcherrimum etc.

Lophocolea heterophylla (Schrad.) Dumort. (per.) - I: 3, 7, 11, 15; IV: 2. (9: 870-941). On decaying wood and logs, rather common in appropriate sites, but rarely collected because it is easy recognized in the field. Occurs often in pure mats [122023] but often mixed with other species of decaying wood e.g. Crossocalyx hellerianus, Scapania carinthiaca, Syzygiella autumnalis etc.

L. minor Nees (gem.) - I: 15; IIa: 6; IIb: 19 (3: 899-1081). On soil in crevices in cliffs and rock outcrops, rare on trail in forests, usually in pure mats [121848].

Lophozia lantratoviae Bakalin (gemm.)-IV: 4. On soil between rocks, mixed with Blepharostoma trichophyllum, Plagiochila porelloides, Scapania degenii, S. mucronata, Tritomaria exsecta [121945, 121946].

L. silvicola H. Buch (per., and., gem.) Sp. - I: 3; IIb: 26; IV: 4 (8: 882-1130). In pure mats or mixed with Tritomaria execta, T. exectiformis, Lepidozia reptans, Blepharostoma trichophyllum [121953].

Lophoziopsis excisa (Dicks.) Konstant. et Vilnet (per., and., gem.) - IIa: 3 (4: 965-1130). On rock [121835] IIb: 26. Three specimens from side of boulders, in deep niche (cold and moist), mixed with Cephaloziella divaricata [121904] or in pure mats [121902, 121909] and one specimen on rock on steep slope [121835] in mats with admixture of Cephaloziella divaricata.

L. longidens (Lindb.) Konstant. et Vilnet. (gem.) - I: 16. On burnt trunk, mixed with Trilophozia quinquedentata, three specimens [122029-31]; IIb: 26. On rock under moss cushions with admixture of Barbilophozia barbata [121906].

Mannia fragrans (Balb.) Frye et L.Clark (spor.) - I: 9. On sandy soil in crevices in pure mats [122000] or with Targionia hypophylla [122001, 122002]; 16. In crevices, some thalli in mats with Arnellia fennica [122027].

Marchantia polymorpha L. subsp. montivagans Bischl. et Boissel.-Dub. (gem.) - IIa: 17. On rocks near water, in pure mats [121920, 21]; IV: 1. On mossy rocks in bed of stream, on wood, mixed with Pellia endiviifolia $[121929,30]$.

M. polymorpha L. subsp. ruderalis Bischl. et Boissel.-Dub. (gem.) - I: 2. On sandy soil between boulders, in pure mats [121968]

Marsupella emarginata (Ehrh.) Dumort. (per.) - IIc: 28:2. In rock fissures, mixed with Herbertus aduncus, Trilophozia quinquedentata [122052] or in pure turfs [122054].

Mesoptychia badensis (Gottsche ex Rabenh.) L. Söderstr. et Váňa (per., and., dioicous) - I: 2, 14, 15, 17. IIa: 1, 3 (8: 899-965). On limestone and soil on ledges and in crevices on cliffs, on steep banks of rivers, on steep walls of steps of trail stairs. Occurs as scattered shoots [121830] or nets over marble or limestone rocks, in several specimens mixed with Chiloscyphus pallescens [122037]. The form with papillose cuticle occurs, e.g. [122020]

M. collaris (Nees) L. Söderstr. et Váňa (per.) - I: 14. On rock among mosses [122019]; IIa: 17. On trail between rising roots and rocks, dominant in mats [121916] and as admixture to Aneura pinguis [121915] or Preissia quadrata [121922].
M. heterocolpos (Thed. ex Hartm.) L. Söderstr. et Ván̆a (gem.) - IV: 4. On rock at the base of steep slope mixed with Blepharostoma trichophyllum, Plagiochila porelloides, Tritomaria exsecta, Scapania mucronata [121939] and on decaying almost destroyed wood mixed with Tritomaria execta, Barbilophozia barbata, Plagiochila porelloides [121940, 41].

M. igiana (S. Hatt.) L. Söderstr. et Váňa (per., and.) - I: 10, 14, 17 (9: 923-1266). On loamy soil covered rocks overhanging by grasses, on slope to the river, on soil covered rocks on steep side to the trail, on steep bank of the river. Several specimens in which the species dominated in mats, admixed are Aneura pinguis, Blepharostoma trichophyllum, Scapania gymnostomophila, S. cuspiduligera. Androecia were not previously known in Russia (Potemkin, et al., 2015). We found it in several specimens. Male bracts [121859,121856] are 2-3 lobed with clearly ventricose antical base, antical lobe much smaller than ventral, in 3-lobed bracts the third lobe much smaller and sometimes with teeth on side, both dorsal lobes ending in 2-3 (4) elongated superposed cells, ventral lobe occasionally blunt. Female bracts on dorsal side sometimes with one or two teeth of one or two slightly elongated cells e.g. [121859].

M. morrisoncola (Horik.) L. Söderstr. et Váňa (per., spor.) - I: 17. On loamy soil on tussocks near water, with Aneura pinguis [ 122035]; II: 13. On vertical rock on rock outcrops, on steep bank to the river, on loamy soil on tussocks in pure mats or with admixture of Pellia endiviifolia [121872] or Preissia quadrata, Aneura pinguis, Blepharostoma trichophyllum [121873]; on steep bank to the river with Preissia quadrata [121918] or with Aneura pinguis, Blepharostoma trichophyllum [121919].

Metzgeria pubescens (Schrank) Raddi - I: 13; IIa: 13; IIb: 20 (5: 933-1190). Among mosses on rocks, in niches under boulders, over mosses on boulder scree on steep slope, in pure mats [122015] or mixed with Porella gracillima [121884] or Scapania degenii [121870].

Oleolophozia perssonii (H. Buch et S.W. Arnell) L. Söderstr., De Roo et Hedd. (gem.) - IIa: 10. On soil, on slope, single pants with characteristic 2-celled angular gemmae with one large oil-body in each cell. [121862]; 14. On soil covered rocks on steep side to the trail single plants with Jungermannia atrovirens [121879].

Pellia endiviifolia (Dicks.) Dumort. (pseudop.) - I: 17. IIa: 13 (5: 853-1190). On rocks in rock outcrops in gorges, on rocks on banks of rivers [122034], once on wood in bed of brook [121929]. In pure mats or with Mesoptychia morrisoncola etc.

P. neesiana (Gottsche) Limpr. (and.) - IV: 1, 3 (3: 853-884). On banks of brooks, rivers, in pure mats [121934] or with Chiloscyphus polyanthus.

Plagiochasma cf. japonicum (Steph.) C. Massal. - I: 9. IIa: 6 (4: 936-1081). In crevices and at the base of cliff on steep bank near waterfall and on soil in ledges, in pure mats [122009].

P. pterospermum C. Massal. (arch, and., spor.) I: 9; IIa: 3, 5, 6; IIc: 26 (8: 900-1081). On soil covered rocks, in crevices and at the base of cliff, on rock outcrops, on soil under the root on the trail in deep gorges of river. Often in pure mats [121840] or mixed with Targionia hypophylla, Reboulia hemisphaerica, Porella gracillima.

Plagiochila porelloides (Torr. ex Nees) Lindenb. (per., andr.) - I: 5; IIa: 6, 7; IV: 1, 4 (15: 882-1739 m). On sand and peat soil, on covered by mosses rocks, decaying almost destroyed 
wood in horizontal crevices in rock outcrops, on banks of rivers, at the base of steep slopes, between rocks on cliff, in pure mats [121849] or mixed with Blepharostoma trichophyllum, Tritomaria exsecta, Scapania mucronata, Frullania davurica etc.

Plectocolea subelliptica (Lindb. ex Heeg) A. Evans - IIc (1: 1500). On stream bank, mixed with Blepharostoma trichophyllum, Trilophozia quinquedentata [122064].

Porella gracillima Mitt. - I: 16; IIa: 5, 11; IIb: 21; IIc: 27 (11: 916-1119). On rocks, on soil covered rocks, on ledges and in crevices of cliffs, in niche under boulders, at the base of cliffs, in pure mats [121838] or mixed with Metzgeria pubescens, Radula complanata, Frullania davurica, Barbilophozia barbata.

P. platyphylla (L.) Pfeiff. - I: 9. In crevices of cliff, in pure mats [122005].

Preissia quadrata (Scop.) Nees (and., spor.) - I: 6, 13, 17; IV: 4 (5: 882-1190). On sandy soil in horizontal crevices of cliffs, on sandy soil on rock outcrops, on banks of rivers. In pure mats [121876] or mixed with Mesoptychia spp.

Ptilidium ciliare (L.) Hampe - IIb: 27 (1:1739). In rock fissures, with Barbilophozia hatcheri [122053]

P. pulcherrimum (Weber) Vain. - I: 3, 7; IIb: 20, 24, 26; IV: 2 (14: 870-1130). On sides of logs, on moist decaying wood in forests, sometimes on mosses covered boulders or between boulders in boulder screes. In pure mats [121992] or mixed with Crossocalyx hellerianus, Scapania carinthiaca, Syzygiella autumnalis, Lophocolea heterophylla, Tritomaria spp. and other species occurring on decaying wood.

Radula complanata (L.) Dumort. (per., spor.) - IIa: 11, 13; IIb: 20; IIc: 28 (990-1739). On soil on ledges of cliff, on rock on sides of huge boulders, in niche under boulder, on bank of streams. In pure mats [121875] or mixed with Metzgeria pubescens, Porella gracillima.

Reboulia hemisphaerica (L.) Raddi subsp. hemisphaerica (spor., paroicous) - I: 2, 9, 16; IIc: 27 (7:907-1000). On bare soil on mossy rock outcrops, under rocks, on ledges and in crevices, in pure mats [121970] or mixed with Plagiochasma pterospermum, Targionia hypophylla, Arnellia fennica.

- subsp. australis R.M. Schust. (arch., and. spor., autoicous, colored female scales) - I: 3, 13; IIa: 4, 6, 20 (6: 898-1081). On sandy soil on marble under grasses overhanging, in crevices, niche and at the base of cliff, under boulders, on sides of track, under cliffs. In pure mats [121837] or with Targionia hypophylla [121979]

Riccardia latifrons (Lindb.) Lindb. - I: 7 (1: 926). On side of log, with admixture of Crossocalyx hellerianus, Scapania carinthiaca [121986]

Riccia cf. cavernosa Hoffm. - III: 1 (1: 711). On side of tussock [121913], single thalli without spores. As a result the exact identification was impossible.

Scapania carinthiaca J.B. Jack ex Lindb. (per., gem.) - I: 3, 7, 11; IIa: 15, 16 (13: 870-1145). On decaying wood in moist, floodplain Populus dominated forests or coniferous (dominated by Larix sibirica and Pinus sibirica) forests in deep gorges. Dominated in mats of common species of decaying wood [121882] or mixed with other liverworts, more often associated with Crossocalyx hellerianus, occurs as well with Tritomaria spp., Syzigiella autumnalis, Ptilidium pulcherrimum etc.

S. crassiretis Bryhn - IV: 1, 3 (4: 853-884), rare. On mossy rock in brook, on soil covered rock on bank of river. In pure turfs
[121923] or mixed with Mesoptychia collaris, Scapania cuspiduligera, S. undulata, Blepharostoma trichophyllum.

S. curta (Mart.) Dumort. (gem.) - I: 1 (2: 916 m). On side of mossy log ca. $60 \mathrm{~cm}$ in diameter mixed with Blepharostoma trichophyllum [121958]

S. cuspiduligera (Nees) Müll. Frib. (gem.) - I; 2; IIa: 10, 13; IV: 3 (13: 884-1266). On soil (loamy or sandy) covered rocks overhanging by grasses, on slope to the river, on steep side to the trail, on boulders and at the base of boulders in deep gorges or along streams. In pure mats [121963] or mixed with Aneura pinguis, Mesoptychia igiana, Scapania gymnostomophila, Blepharostoma trichophyllum, etc.

S. degenii Schiffn. ex Müll. Frib. (gem.) - IIa: 11, 13, 18; IIc: 28; IV: 4 (8:1119-1739). - On soil between rocks, in crevices and in niches on cliffs, on soil covered rock on side of huge boulder, among mosses on rock, on soil covered rocks on trail, on steep side to the trail. Occurs in pure turfs [121865] or mixed with Porella gracillima, Frullania davurica, Tritomaria quinquedentata, Radula complanata, Blepharostoma trichophyllum, Plagiochila porelloides etc.

S. gymnostomophila Kaal. (gem.) - I: 13, 16; IIa: 5, 10, 14; IIc: 27, 28 (10: 916-1739). On moist cliffs, on loamy soil covered rocks and cliffs often overhanging by grasses on slope to the river in deep gorges, on soil covered rocks on steep side to the trail, once on cliff among mosses on mossy decaying wood. Occurs in pure mats [122018] or mixed with $M e$ soptychia igiana, Scapania cuspiduligera, rarely with Frullania koponenii.

S. irrigua subsp. rufescens (Loeske) R.M. Schust. (gem.) The species was found in collection of Schevyreva N. \& T. Konovalov [122063] at ca. $1500 \mathrm{~m}$ alt., along brook. We referred the specimen to this variety based on rounded leave lobes and distally reddish-brown colored leaves.

S. mucronata H. Buch (per., and., gem.) - IIc: 28, IV: 4 (6: 8821739). On rock at a base steep slope, in rock fissures, mostly mixed with other liverworts [121945], particularly Trilophozia quinquedentata, Blepharostoma trichophyllum, Tritomaria exsecta, Plagiochila porelloides etc.

S. parvifolia Warnst. (per., spor., gem.) - IV: 4 (2:882 m). On trail, between stick out roots, dominated in mats with admixture of Tritomaria exsecta, Trilophozia quinquedentata, Lophozia silvicola, Blepharostoma trichophyllum [121949].

S. praetervisa Meyl. (gem.) - IV: 4 (1: $882 \mathrm{~m})$. On boulder, with Trilophozia quinquedentata_ [121942], oil-bodies (3)4$6(7)$ per cell ca. $2-4 \times 5-7(10) \mu \mathrm{m}$, gemmae green to red tinged.

S. scandica (Arnell et H. Buch) Macvicar (per.) - IV: 1 (1: 853 $\mathrm{m})$. On rock in bed of brook, with Chiloscyphus polyanthos [121925].

S. undulata (L.) Dumort. - IV: 3 (2: 884 m). On soil covered rock on bank of river, mixed with Jungermannia borealis, Blepharostoma trichophyllum, Scapania crassiretis, Mesoptychia collaris, Scapania cuspiduligera [121937].

Schistochilopsis incisa (Schrad.) Konstant. (gem.) - I: 4 (1: 900) dominating on decaying log with admixture of Lepidozia reptans [121981]

Sphenolobus saxicola (Schrad.) Steph. - IIb: 25 (1: 1047 m). Between boulders, in huge pure mats [121897].

Syzygiella autumnalis (DC.) K. Feldberg, Váňa, Hentschel et Heinrichs (per., and., spor.) - I: 7, 11; IIb: 23, 24, 25 (14: $870-1130 \mathrm{~m}$ ). On moist decaying wood of Pinus sibirica or Larix sibirica, rare at the base of boulder or among mosses 
on mosses covered boulders in coniferous or mixed forests on slopes of mountains or in floodplains of rivers, dominated in mats [121893] or mixed with Crossocalyx hellerianus, Ptilidium pulcherrimum, Scapania carinthiaca, Tritomaria exsecta etc.

Targionia hypophylla L. (spor.) - I: 3, 9, 12; IIa: 18; IIc: 26 (898-1235). On sandy soil in crevices in rock outcrops, on steep slopes, under cliff, on ledges of cliffs, on soil under grasses on steep slopes, in pure mats [122014] or mixed with Mannia fragrans, Reboulia hemisphaerica, Plagiochasma pterospermum.

Trilophozia quinquedentata (Huds.) Bakalin (gem., per.) - I: 16; IIa: 7, 11, 18; IIb: 25; IIc: 28; IV: 4 (17: 882-1739). On soil and mosses covered rocks and under boulders, on trails, between stick out roots, once on burnt trunk in rock scree, in rock fissures. In mats without admixture of other liverworts [121898] or mixed with Lophoziopsis longidens, Blepharostoma trichophyllum, Tritomaria exsecta, Lepidozia reptans, Plagiochila porelloides, Frullania davurica etc.

Tritomaria exsecta (Schmidel) Schiffn. ex Loeske (gem.) - I: 3, 4, 7; IIa: 7, 14; IV: 4 (22: 882-1190). On soil and mosses covered rocks and between rocks, at the base of steep slopes, once along the trail, in niche of stick out roots, on moist log and decaying almost destroyed wood. In pure mats [121982] or more often mixed with other liverworts, particularly Crossocalyx hellerianus, Trilophozia quinquedentata, Lepidozia reptans, Plagiochila porelloides, Blepharostoma trichophyllum, Mesoptychia heterocolpos etc.

T. exsectiformis (Breidl.) Schiffn. ex Loeske. (gem.) - I: 3; Ila: 26; IV: 2 (7: 870-1130). On decaying logs in mixed forests, once on soil in niche on boulder scree. In pure mats [121910] or mixed with Tritomaria exsecta, Crossocalyx hellerianus, Scapania carinthiaca, Lepidozia reptans, Tritomaria exsecta etc.).

\section{DISCUSSION}

The compiled list of liverworts includes 75 species, one subspecies and two varieties and is obviously incomplete. The specific features of the liverwort flora of Tunka National Park lies in the relatively large amount of obligate calcicoles owing to the presence of interstratified calcareous shales and marbles. This group includes some Holarctic arctic-boreomontane liverworts relatively widespread in calcareous areas (Mesoptychia collaris, $M$. badensis, Scapania cuspiduligera, Preissia quadrata, Jungermannia atrovirens) as well as more rare, sporadic arctic-montane species (Arnellia fennica, Oleolophozia perssonii, Scapania gymnostomophila, Clevea hyalina). We also found some calcicoles with a more southern general distribution, such as Lophocolea minor, Mannia fragrans, Pellia endiviifolia, Plagiochasma japonicum, $P$. pterospermum, Reboulia hemisphaerica, Targionia hypophylla, as well as the worldwide rare disjunct species, $M e$ soptychia igiana and M. morrisoncola.

Among the most phytogeographically interesting records is the discovery of Mesoptychia igiana in the park. The species was recently found in Russia in the Republic of Buryatia in Stanovoye Nagor'e Uplands and in the Okinsky District, East Sayan Mts. in altitude range from 1475 to 1986 m alt., as well as in the Dzherginskiy Strict nature Reserve (Potemkin et al., 2015, Mamontov et al., 2018). It is an East Asian species that apart of Buryatia occurs in China (Sichuan, Yunnan) and Japan (Honshu, Shikoku, l.c.). The findings in Tunka National Park are from elevations lower (923-1266 m alt.) than was known before. Male plants of Mesoptychia igiana were found in the collected specimens and described for Russia for the first time (see above). The finding of $\mathrm{Me}$ soptychia morrisoncola deserves to be mentioned as well. This temperate East Asiatic species was so far only known in Russia from the Irkutsk Province (Bakalin, 2003; Mamontov \& Konstantinova, 2017).

The second characteristic of the park flora is the presence of liverworts with predominantly East Asian distribution. Some of them (Frullania koponenii, F. davurica, F. parvistipula, Plagiochasma japonicum, Porella gracillima) are not rare in the park and can be even abundant in appropriate sites (e.g. Porella gracillima, Frullania davurica). But two species of this group, Frullania cleistostoma and Lophozia lantratoviae, were collected in single locality only.

Three liverworts species of decaying wood that are considered relatively rare in South Siberia, namely $\mathrm{Ca}$ lypogeia suecica, Crossocalyx hellerianus, and Scapania carinthiaca occur sporadically in the park.

The majority of the collected liverwort species are more or less widespread in South Siberia. It should be mentioned that several species recorded recently as new for the Republic of Buryatia (Mamontov et al., 2018), namely Mesoptychia badensis and Pellia endiviifolia were collected in the park, and the first species is rather common in appropriate sites.

Two liverworts (Plagiochasma japonicum and Porella gracillima) included in Red Data Book of Republic of Buryatia (Afonina et al., 2013) were found in Tunkinskiy National Park. Of them Porella gracillima is rather common and abundant in appropriate sites in the park.

\section{ACKNOWLEDGEMENTS}

Anders Hagborg is gratefully acknowledged for correction of English. The study is partly supported by RFBR 18-04-00594.

\section{LITERATURE CITED}

[AFONINA, O.M., E.A. IGNATOVA, S.G. KAZANOVSKY, N.A. KONSTANTINOVA, YE.I. KOSOVICH (KOSOVICH-ANDERSON), YU.S. MAMONTOV \& D. YA. TUBANOVA] AФOHИНA O.M., E.A. ИГНАТОВА, С.Г. КАЗАНОВСКИЙ, Н.А. КОНСТАНТИНОВА, Е.И. КОСОВИЧ (КОСОВИЧ -АНДЕРСОН), Ю.С. МАМОНТОВ, Д.Я. ТУБАНОВА. 2013. Печеночные мхи. - [Hepatics] $B$ кн.: Красная книга Республики Бурятия: Редкие и находящиеся под угрозой исчезновения виды животных, растений и грибов. Изд. 3-е, перераб. и доп. (ред. Пронин, Н.М.) Улан-Удэ, Бурятский научный иентр CO PAH [In: Pronin, N.M. (ed.) The Red Data Book of Buryatia: Rare and Endangered Species of Animals, Plants and Fungi. 3rd ed., rev. and enl. Ulan-Ude, Buryat Scientific Center SB RAS Publisher]: 393-412.

[AFONINA, O.M., YU.S. MAMONTOV, D.YA. TUBANOVA, I.V. CZERNYADJEVA \& S.G. KAZANOVSKY] АФОНИНA О.M., Ю.С. МАМОНТОВ, Д.Я. ТУБАНОВА, И.В. ЧЕРНЯДЬЕВА, С.Г. КАЗАНОВСКИЙ. 2018. К флоре мохообразных полуострова Святой Нос озера Байкал (Бурятия). - [On bryophyte flora of Svyatoi Nos Penin- 
sula (Zabaikalsky National Park, Republic of Buryatia)] Ботанический журнал [Botanicheskii Zhurnal] 103(4): 466-487.

[AFONINA, O.M., YU.S. MAMONTOV \& I.V. CZERNYADJEVA] АФОНИНА О.М., Ю.С. МАМОНТОВ, И.В. ЧЕРНЯДЬЕВА. 2012. Мхи и печеночники Сохондинского государственного заповедника. - [Mosses and liverworts of the Sokhondinsky State Reserve] СПб, Изд-во СПбГЭТУ “ЛЭТИ" [St. Petersburg: Publishing house of ETU, $211 \mathrm{pp}$.

[AFONINA, O.M., YU.S. MAMONTOV \& I.V. CZERNYADJEVA] АФОНИНА О.М., Ю.С. МАМОНТОВ, И.В. ЧЕРНЯДЬЕВА. 2013. Новые и редкие виды печеночников и мхов для Забайкальского края. - [The records of new and rare liverwort and moss species from Zabaikalsky Territory] Ботанический журнал [Botanicheskii Zhurnal] 98(11): 1427-1440.

BAKALIN, V.A. 2003. The status and treatment of the genus Hattoriella (H. Inoue) H .Inoue. - Arctoa 12: 91-96.

CZERNYADJEVA, I.V., YU.S. MAMONTOV \& O.M. AFONINA. 2013. On bryophyte flora of Atsinskiy Sanctuary (Zabaikal'sky Territory, South Siberia). - Arctoa 22: 217-222.

[MAMONTOV, YU.S.] MAMOHTOB Ю.C. 2013a. The genus Ascidiota C. Massal. (Porellaceae, Hepaticae) new to Russia. - В кн.: Интеграичи ботанических исследований и образования: традиции и перспективы: Труды Международной научно-практической конференции, посвященной 125-летию кафедры ботаники (12-15 ноября 2013, Томск). Томск: ТГУ [In: Integratsiya botanicheskikh issledovaniy i obrazovaniya: traditsiii i perspektivy: Trudy Mezhdunarodnoy nauchno-prakticheskoy konferentsii, posvyashchennoy 125letiyu kafedry botaniki (12-15 noyabrya, 2013, Tomsk). Tomsk: Izdvo Tomskogo Univ.]: 107.

[MAMONTOV, YU.S.] МАMOНTOB Ю.С. 2013b. Печеночники окрестностей Мультинских озер (Катунский хребет, Южная Сибирь). - [The Hepaticae of the Mul'tinskije lakes surroundings (Katunsky Range, South Siberia)] Arctoa 22: 223-228.

MAMONTOV, YU.S. \& O.M. AFONINA. 2012. New liverwort records from Zabaikal'sky Territory. 6. - Arctoa 21: 290-294.

[MAMONTOV, YU.S. \& N.A. KONSTANTINOVA] MAMOHTOB Ю.С., Н.А. КОНСТАНТИНОВА. 2017. Печеночники (Marchantiophyta) Иркутской области. - [Liverworts (Marchantiophyta) of Irkutsk Region] Ботанический журнал [Botanicheskii Zhurnal] 102(4): 494-519.

MAMONTOV, YU.S., N.A. KONSTANTINOVA \& O.M. AFONINA. 2011. New liverwort records from Zabaikal'sky Territory. 5. - Arctoa 20: 259-261.
[MAMONTOV, YU.S., A.D. POTEMKIN, D.YA. TUBANOVA \& E.V. SOFRONOVA] MAMOHTOB Ю.С., А.Д. ПОТЕМКИН, Д.Я. ТУБАНОВА, Е.В. СОФРОНОВА. 2018. Печеночники Джергинского заповедника (Республика Бурятия). - [Liverworts of the Dzherginsky Reserve (Republic of Buryatia)] Новости систематики низиих растений [Novosti sistematiki nizshikh rastenii] 52(2): 483-504.

MAMONTOV, YU.S. \& A.A. VILNET. 2013. Anastrophyllum ellipticum Inoue (Jungermanniales, Marchantiophyta) - new species for Russian liverwort flora. - Arctoa 22: 151-158.

MAMONTOV, YU.S. \& A.A. VILNET. 2017. Cephaloziella konstantinovae (Cephaloziellaceae, Marchantiophyta), a new leafy liverwort species from Russia and Mongolia identified by integrative taxonomy. - Polish Botanical Journal 62(1): 1-19.

POTEMKIN, A.D., YU.S. MAMONTOV, E.V. SOFRONOVA \& O.I. KUZNETSOVA. 2015. Mesoptychia igiana (S. Hatt.) L. Söderstr. et Váňa (Jungermanniaceae, Marchantiophyta) in Russia. - Arctoa 24(2): 489-496.

[SIDORENKO, A.V. (ed.)] СИДОРЕНКО А.В. (ред.). 1964. Геология CCCP, Том XXXV, Бурятская АCCP, Часть I, Геологическое описание. - [Geologiya SSSR, Tom XXXV, Buryatskaya ASSR, Chast' I, Geologicheskoe opisanie] М., Изд-во "Hедра" [Moscow, Nedra Press]: $630 \mathrm{pp}$.

SÖDERSTRÖM, L, A. HAGBORG, M. VON KONRAT, S. BARTHOLOMEW-BEGAN, D. BELL, L. BRISCOE, E. BROWN, D.C. CARGILL, D.P. COSTA, B.J. CRANDALL-STOTLER, E.D. COOPER, G. DAUPHIN, J.J. ENGEL, K. FELDBERG, D. GLENNY, S.R. GRADSTEIN, X. HE, J. HEINRICHS, J. HENTSCHEL, A.L. ILKIUBORGES, T. KATAGIRI, N.A. KONSTANTINOVA, J. LARRAÍN, D.G. LONG, M. NEBEL, T. PÓCS, F. FELISA PUCHE, E. REINERDREHWALD, M.A.M. RENNER, A. SASS-GYARMATI, A. SCHÄFER-VERWIMP, J.G.S. MORAGUES, R.E. STOTLER, P. SUKKHARAK, B.M. THIERS, J. URIBE, J. VÁŇA, J.C. VILLARREAL, M. WIGGINTON, L. ZHANG \& R.-L. ZHU. 2015. World checklist of hornworts and liverworts. - PhytoKeys 59: 1-828.

SOFRONOVA, E.V., YU.S. MAMONTOV \& A.D. POTEMKIN. 2014. Frullania sinensis Steph. - In: New national and regional bryophyte records, 41. Journal of Bryology 36(4): 310-311.

[TUBANOVA, D.YA., YU.S. MAMONTOV, O.M. AFONINA \& A.D. POTEMKIN] ТУБАНОВА, Д.Я., Ю.С. МАМОНТОВ, О.М. АФОНИНА, А.Д. ПОТЕМКИН. 2017. Новые и редкие виды во флоре мхов и печеночников Республики Бурятия. - [New and rare species in the moss and liverwort flora of the Republic of Buryatia] Bomaнический журнал [Botanicheskii Zhurnal] 102(10): 1442-1454. 